\title{
Analysis of the efficiency of the Iberian power futures market
}

\author{
Álvaro Capitán Herráiz*, Carlos Rodríguez Monroy \\ Department of Business Administration, Madrid Technological University (UPM), José Gutiérrez Abascal, 228006 Madrid, Spain
}

A R T I C L E I N F O

Keywords:

Iberian Power Futures Market

Market efficiency

Forward risk premium

\begin{abstract}
A B S T R A C T
Market efficiency is analysed for the Iberian Power Futures Market and other European Power Markets, as well as other fuel markets through evaluation of ex-post Forward Risk Premium. The equilibrium price from compulsory call auctions for distribution companies within the framework of the Iberian Power Futures Market is not optimal for remuneration purposes as it seems to be slightly upward biased. In the period considered (August 2006-July 2008), monthly futures contracts behave similarly to quarterly contracts. Average risk premia have been positive in power and natural gas markets but negative in oil and coal markets. Different hypotheses are tested regarding increasing volatility with maturity and regarding Forward Risk Premium variations (decreasing with variance of spot prices during delivery period and increasing with skewness of spot prices during delivery period). Enlarged data sets are recommended for stronger test results. Energy markets tend to show limited levels of market efficiency. Regarding the emerging Iberian Power Futures Market, price efficiency is improved with market development of all the coexistent forward contracting mechanisms and with further integration of European Regional Electricity Markets.
\end{abstract}

\section{Introduction}

Since its beginning in July 2006, the Iberian Power Futures Market managed by Iberian Forward Market Operator (OMIP), within the framework of the Iberian Electricity Market (MIBEL), has experienced a continuous development, in terms of number of participants and liquidity. At this moment, around 30 market players participate in OMIP. Almost half of them (12) belong to Iberian energy incumbents (vertically integrated energy groups with separated generation and distribution companies). Only six members are pure financial agents, still a reduced figure. Additionally, only two market makers have been active in OMIP: RBS Sempra quoting monthly contracts in the periods September 2007-March 2008 and May 2008-October 2008, and EGL Spain quoting quarterly and yearly contracts in the period November 2008-April 2008. The main amount of traded energy in OMIP is still driven by compulsory call auctions according to national regulations aimed at fostering the MIBEL. The Spanish distribution companies and the Portuguese last resort supplier with more than 100,000 clients are obliged to purchase in these auctions, in order to partly cover their portfolios of end-user-regulated supplies. Such an obligation comprises $5 \%$ of their regulated supplies, for

\footnotetext{
* Corresponding author.

E-mail addresses: alvarocapitan@hotmail.com (A. Capitán Herráiz), crmonroy@etsii.upm.es (C. Rodríguez Monroy).
}

the 2nd half of year 2006, as agreed by MIBEL Council of Regulators in the Évora Summit (November 2005), and published in the corresponding legislation (Spanish Order ITC/2129/2006 and Portuguese "Portaria" 643/2006), and 10\% for year 2007 onwards, as agreed in the Badajoz Summit (November 2006), and published in Spanish Order ITC/3990/2006 and Portuguese Dispatch $780 / 2007$ (for 1st half of year 2007), Spanish Order ITC/1865/2007 and Portuguese Dispatch /2007 of 29 June, 2007 (for 2nd half of year 2007 and 1st half of year 2008), Spanish Order ITC/1934/2008 and Portuguese Dispatch 19098/2008 (for 2nd half of year 2008), and Spanish Order ITC/3789/2008 and Portuguese Dispatch 125-A/2009 (for 1st half of year 2009) (Fernández Domínguez and Xiberta Bernat, 2007; Capitán Herráiz and Rodríguez Monroy, 2009).

As shown in Fig. 1, since the last quarter of 2007 the amount of energy traded in the OMIP continuous market has grown slightly compared to previous trading levels, with a record in June 2008, though it is still less than the auctioned amounts. In the first two years of OMIP continuous market (i.e., since July 2006 until July 2008), the accumulated amount of energy traded in OMIP call auctions is more than five times bigger than in the continuous market. Within the first two years of OMIP, despite the record level in June 2008, no generalised trend of increasing volumes is appreciated in the continuous market. Therefore, liquidity of this market is still reduced compared to other European Power Futures Markets.

An analysis of the efficiency of the Iberian Power Futures Market is done to assess the situation of this emerging market. 


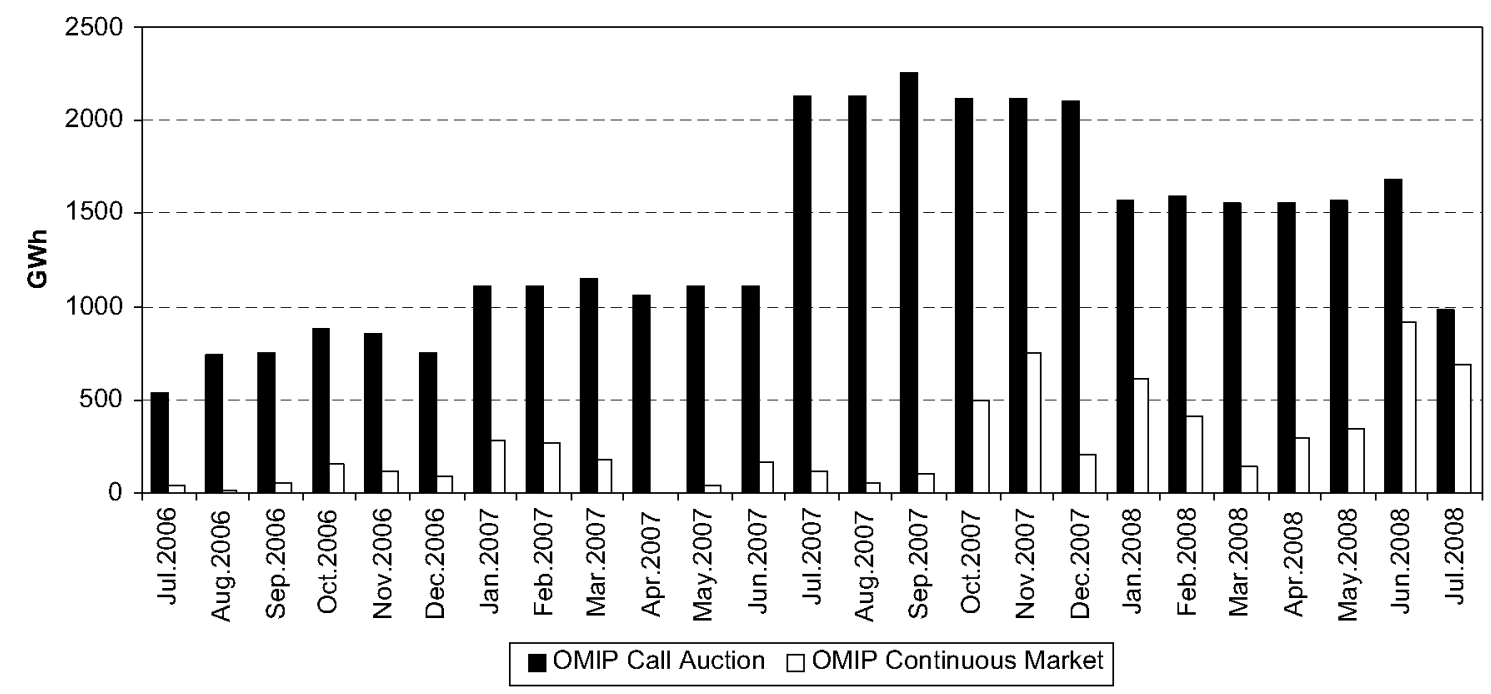

Fig. 1. Evolution of trading levels (GWh) in OMIP call auctions and OMIP continuous market.

This information is of special interest both for all MIBEL market players and for MIBEL Regulatory Committee in charge of MIBEL market supervision. In order to perform this analysis, the article is structured as follows: Section 2 Iberian Power Futures Market describes how OMIP call auctions and OMIP continuous market work, as well as other coexisting forward contracting mechanisms within MIBEL scope, namely, the so-called EPE auctions (in Spanish "Emisiones Primarias de Energía", commonly known in English as virtual power plant (VPP) auctions) and CESUR auctions (in Spanish "Contratos de Energía para Suministros de Último Recurso", i.e., last resort supply auctions); Section 3 Literature Review about Market Efficiency briefly describes the main studies regarding price efficiency of energy and other commodity markets; Section 4 Definition of the Ex-post Forward Risk Premium, builds that premium as the difference between the average settlement price of a futures contract and the resulting average spot price during delivery (e.g., Furió and Meneu, 2009), and constitutes it as the driver of the diverse tests performed in the following Sections; Section 5 Test 1 Assessment of OMIP Auction Equilibrium Prices assesses if the price formation in OMIP call auctions is satisfactory; Section 6 Test 2 Analysis of Basic Statistics of Futures \& Spot Prices compares the price evolution of various energy markets; Section 7 Test 3 Analysis of Ex-post Forward Risk Premium magnitudes assesses the Forward Risk Premium existence and compares the futures behaviour towards maturity of these energy markets; Section 8 Test 4 Bessembinder's and Lemmon's hypothesis compliance analyses the compliance of OMIP, Powernext and Nord Pool Power Markets regarding the hypothesis derived from seminal research based upon an equilibrium model by Bessembinder and Lemmon (2002), claiming that the Forward Risk Premium decreases in the variance of spot prices and increases in the skewness of wholesale prices; finally, Section 9 Conclusions summarises the findings of this research and proposes future developments related to this topic.

\section{Iberian power futures market}

Since November 18th, 2008, the Iberian Power Futures Market has the EU Regulated Market status, according to Directive 2004/ 39/EC of the European Parliament and of the Council of April 21st, 2004 on markets in financial instruments (MiFID), following the registration with the Portugese Securities Market Commission (Comissão do Mercado de Valores Mobiliários, CMVM) on October 30th, 2008. Whereas OMIP works as Market Operator of the MIBEL Derivatives Market, OMIClear acts as the Clearinghouse. There are two trading modes coexisting within OMIP: the continuous market (default mode) and the call auction. In the continuous trading, anonymous buy and sell orders interact immediately and individually with opposite side orders, generating trades with an undetermined number of prices for each contract. Buy orders with the highest prices and sell orders with the lowest prices are executed first. In the call auction trading, a single-price auction maximizes the traded volume, being all trades settled at the same price (equilibrium price). The call auction algorithm is based on the maximum tradable volume and minimum price criteria, following a First In First Out allocation method. Additionally, OMIP trading members may settle Over The Counter (OTC) trades through OMIClear, either registrating their transactions by themselves or through a broker, experiencing this activity a remarkable growth in the last quarter of year 2008 due to the difficulties of holding credit lines in the current global financial turmoil. OMIP trading sessions are composed of the following time windows: pre-trade phase happens between $8 \mathrm{a} . \mathrm{m}$. and 9 a.m.; auction phase between 9 a.m. and 9:10 a.m.; continuous trading phase between 9:10 a.m. and 4:30 p.m.; and pre-close phase between $4: 30 \mathrm{p} . \mathrm{m}$. and $6: 30 \mathrm{p} . \mathrm{m}$. The first four Wednesdays of each month, the auction phase is extended until $10 \mathrm{a} . \mathrm{m}$. as the compulsory call auctions where Spanish distribution companies and the Portuguese last resort supplier are to purchase regulatorily fixed volumes occur (OMIP OMIClear, 2008).

As stated by Martín Martínez and Villaplana (2009), the current regulatory development in Spain and Portugal towards the establishment of last resort tariffs competing with the liberalised market will foster the electricity derivatives use as hedging instruments for the market players. In this sense, since June 2007 other forward contracting mechanisms based on compulsory auctions have been created, namely: virtual power plant auctions (in Spanish, the so-called "Emisiones Primarias de Energia" or EPE auctions), and the last resort supply auctions (in Spanish, the so-called "Contratos de Energía para Suministros de Último Recurso" or CESUR auctions). The coexistence of these instruments is boosting the liquidity of energy derivatives for risk management purposes, both within OMIP market as well as in the OTC market, the latter already active since 1999. The Royal Decree 1634/2006, of 29 December, established the five first EPE auctions with physical delivery. In these auctions, call options regarding "virtual" capacity of the Spanish incumbent generators (Endesa 
and Iberdrola) are auctioned following a multi-round ascending clock algorithm in order to mitigate market power, as previously done in other European and North American markets. The successful bidders pay the option price and are thus granted with the right to access to this power capacity. When the option expires, if the successful bidder wants to execute the option, he pays for the strike price that was previously fixed as these options are of European nature. These electronic auctions are regulated by the Ministry of Industry, Trade and Commerce (MITyC), supervised by the Spanish Energy Regulator (Comision Nacional de Energía or CNE), and managed by and independent entity. The equilibrium price is got when the demand equals the targeted volume at a price bigger than the reserve price. The Royal Decree $324 / 2008$, of 29 February, establishes a calendar for the sixth and seventh EPE auctions, in this case both settled by differences, being celebrated in September 2008 and March 2009. On the other hand, the CESUR auctions are a forward contracting mechanism for the Spanish distribution companies and the Portuguese last resort supplier, complementing their procurements in the OMIP call auctions as well as in the spot market. The CESUR auctions have facilitated the entry of new agents and foster the development of the coexisting forward contracting mechanisms. The CESUR auctions, as stated in Order ITC/400/2007, of 26 February, will contribute to the price valuation of the energy included in the last resort tariffs, and will prevent further undesirable regulated tariff deficits. The CESUR auctions are also regulated by MITyC, supervised by CNE, and managed by an independent entity. They are also electronic though based on a multi-round descending clock algorithm. In CESUR auctions, the equilibrium prices are got when the demand equals the targeted volume. Extensive analysis of the celebrated EPE and CESUR auctions is provided by Federico and Vives (2008). They conclude that the EPE dimension (i.e., the offered capacity by the incumbents) is still limited and these auctions have dealt so far short-duration contracts, thus rendering relatively ineffective regarding market power reduction goals. They also conclude that CESUR auctions are unlikely to have a strong pro-competitive impact in the market, as there is no obligation to participate. Nevertheless, they think that the introduction of longer contracts in CESUR auctions would improve the price valuation of the energy component of the last resort tariff.

\section{Literature review about market efficiency}

A short literature review of market efficiency is provided, focused on energy markets, and especially, in power markets compared to other commodities and to other financial markets. Market efficiency mainly refers in this context about how well the future price predicts the spot price.

Co-integration tests as well as tests for measuring if the forward price is an unbiased forecast for cash price for commodity and power markets show that futures markets are efficient in the long term, but not in the short term, even if risk neutrality is neglected and a risk premium is assumed. In practice, the hypothesis claiming that forward price is an unbiased forecast of future cash price ("Efficient Market Hypothesis") is usually rejected (Engel, 1996).

According to statistics and econometric research, many commodity futures markets existing since the middle of the 19 th century are not efficient. Power markets are considerably younger than commodity markets due to the deregulation trend in the 1990s. Power markets differ from other markets since electricity storage is very limited. There are many studies for the US and European Power Markets, analysing the behaviour and interactions of their different regional markets.
Regarding energy markets, Serletis (1992) examines the effects of maturity on futures price volatility and trading volume for 129 energy futures contracts traded in New York Mercantile Exchange (NYMEX) in the beginning of the 1990s. The results provide support for the maturity effect hypothesis theoretically demonstrated by Samuelson (1965). In the applied Serletis' research, energy futures prices become more volatile and trading volume increases as futures contracts approach maturity.

Regarding US Power Markets, there are many studies comparing different regional markets. Arciniegas et al. (2003) detects that the Pennsylvania/New Jersey/Maryland (PJM) Power Market and the California Power Market are more efficient than the New York Power Market. Avsar and Goss (2001) study market efficiency for the PJM and the California Power Markets and cannot reject the efficient market hypothesis for the period July 1998-March 1999 , but cannot accept it for the whole data period. They find remarkable learning effects from market agents. Additionally, market efficiency is linked to market maturity. In this sense, market players in power markets seem to learn faster than in oil markets, for instance, increasing its efficiency with time (Walls, 1999). Bessembinder and Lemmon (2002) consider that electricity cannot be economically stored and therefore, arbitrage-based methods are not applicable for pricing power derivative contracts. They build an equilibrium model implying that the forward power price is a downward-biased predictor of the future spot price if expected power demand is low and demand risk is moderate. The equilibrium forward risk premium, understood as the bias in the forward price as a predictor of the delivery-date spot price, increases when either expected demand or demand variance is high, due to positive skewness induced in the spot power price distribution. Optimal forward positions for power producing and retailing firms depend on forecast power demand and on skewness of power prices. Premium in forward power prices is positively related to expected demand, and is large during summer. Longstaff and Wang (2004) perform an empirical analysis of forward prices in PJM power market with hourly data set of spot and day-ahead forward prices. They find remarkable Forward Risk Premia in power prices and obtain results consistent with Bessembinder's and Lemmon's model. They find that premia vary systematically through the day and are related to agents' measures of economic risk (volatility of unexpected changes in demand, spot prices, and total revenues). They conclude that PJM forward prices are determined rationally by risk-averse economic agents, not applying such finding to other power markets more exposed to market abuse. Ullrich (2007) streamlines Bessembinder's and Lemmon's model considering the constrained capacity, allowing the model to reproduce price spikes by using reasonable parameter values. He finds that the Forward Risk Premium decreases/increases in spot price variance when the expected spot price is low (i.e., less than the retail price)/high (bigger than the retail price), because of retailers' hedging needs. The enlarged PJM data set from Longstaff's and Wang's empirical research supports these model predictions.

Regarding European Power Markets, the largest number of studies exists for Nord Pool, the most developed power market in Europe since its foundation in 1993 (e.g., Byström, 2003). Byström concludes that traditional simple price hedging models are almost equally efficient as the most advanced ones. Therefore, hedging at Nord Pool (or whatever power futures market) does not request more advanced models than from other financial markets though underlying product features differ noticeably from other financial or commodities products. The researches regarding European markets are usually focused on the regional integration of the power markets (e.g., Armstrong and Galli, 2005; Zachmann, 2005). Armstrong and Galli study European wholesale spot power prices and detect a price convergence between the price 
differences. Zachmann also finds a price convergence during the 2002-2004 period between Dutch and German wholesale power prices but not between East Danish and German prices. He concludes that it is necessary to overcome the bottlenecks in the physical interconnection capacity in order to achieve an integration of the European Power Market. Regarding research focused on the Forward Risk Premium, Karakatsani and Bunn (2005) classify half-hourly trading periods in two clusters (peak and offpeak) discovering a systematic diurnal reversal in the forward premium nature for the British Power Market after the market reforms in year 2001. The reversal can be explained by the asymmetric positions of generators and suppliers towards risk and its intra-day variation, due to the heterogeneity of the powergeneration mix and to market design specificity (introduction of penal balancing prices and abolishment of capacity payments and uniform pricing). Ex-ante forward premia, built upon predictive intervals and based on expected spot prices, are similar to ex-post premia but sensitive to assumptions on agents' spot price model, information set and learning scheme. Cartea and Villaplana (2008) build a model for wholesale power prices explained by two state variables (demand and capacity) and calculate the forward premium. They perform empirical research embracing PJM, England and Wales, and Nord Pool markets. They find that, depending on the market and the period under study, the volatility of capacity and the market price of capacity risk could either put upward or downward pressure on forward prices. They also find that the forward premium follows a seasonal pattern, being positive in the months of high volatility of demand and close to zero or even negative in the months of low volatility of demand. Furió and Meneu (2009) perform theoretical and empirical research (based on OTC prompt month forward prices and spot prices of the Spanish Power Market) and find that the exante forward premium varies with the expected demand in tight market conditions, and the ex-post forward premium depends on the unexpected variations in demand and hydro capacity. They also find a positive relation between the Spanish spot prices and the $\mathrm{CO}_{2}$ emission allowance prices. The implications derived from Bessembinder's and Lemmon's model are supported by their data.

Conclusions from existing studies measuring the efficiency of futures markets vary considerably. Reviewed literature shows no uniformity regarding the results provided by the existing measuring methods. The selected method can slightly bias the results. Additionally, the most advanced models may question previous results from older and simpler models. More advanced models tend to confirm market efficiency but older ones may be prone to reject it. In general, it seems that commodity, energy, and even power markets are not especially efficient (STEM, 2006).

\section{Definition of the ex-post forward risk premium}

The present research is focused on the analysis of the Forward Risk Premium in the Iberian Power Futures Market comparing different settlement price criteria and comparing the magnitudes of such risk premium with other European Power Markets and even other fuel markets of interest. There are some studies regarding market efficiency based on the evaluation of Forward Risk Premium. Some of those studies are based on theoretical "exante" analysis by modelling-forecasted spot prices. Other studies use empirical data and evaluate "ex-post" the differences between the futures and spot prices. This research represents an empirical analysis using the "ex-post" Forward Risk Premium.

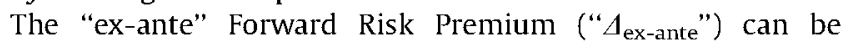
mathematically expressed as follows:

$A_{\text {ex-ante }}=F_{\mathrm{t}, \mathrm{T}}-E_{\mathrm{t}}\left(S_{\mathrm{T}}\right)$ where $F_{t, T}$ refers to the futures power price observed on day " $t$ " for delivery over period " $T$ ", and $E_{\mathrm{t}}\left(S_{\mathrm{T}}\right)$ refers to expected spot price on day " $t$ " for delivery over period " $T$ ".

The "ex-post" Forward Risk Premium (" $A_{\text {ex-post") can be }}$ mathematically expressed as follows:

$\Delta_{\text {ex-post }}=F_{\mathrm{t}, \mathrm{T}}-\operatorname{Average}\left(S_{\mathrm{T}}\right)$

where average $\left(S_{\mathrm{T}}\right)$ refers to average spot price for delivery over period $T$.

In this research, the considered futures contracts are base load and with monthly and quarterly maturity. Three European Power Markets are considered, with all their prices in $€ / M W h$ : OMIP (Iberian Market), Powernext (French Market), and Nord Pool (Nordic Market). The considered fuel markets correspond to oil (InterContinental Exchange (ICE) Brent futures; only monthly futures are analysed, expressed in US\$/Bbl), natural gas (ICE monthly futures and over the counter quarterly Platts' assessments, all related to the British National Balancing Point (NBP), and expressed in GB pence/therm), and coal (European Energy Exchange (EEX) Amsterdam-Rotterdam-Antwerp (ARA) Coal Futures, related to the underlying Argus McCloskey weekly spot index, expressed in US\$/t).

As different monetary units and energy units are used (original units for each market), Forward Risk Premium expressed in percentage over the futures price is preferred when comparing all these markets. Such an expression is mathematically written as follows (e.g., Furió and Meneu, 2009):

$$
A_{\mathrm{ex}-\mathrm{post} \%}=\left[F_{\mathrm{t}, \mathrm{T}}-\operatorname{Average}\left(S_{\mathrm{T}}\right)\right] / F_{\mathrm{t}, \mathrm{T}}
$$

The selected period for the study corresponds to the first two years of existence of OMIP market, which started on 3rd July, 2006. Therefore, the monthly contracts span from August 2006 to July 2008, and the quarterly ones from Q4-06 to Q2-08.

\section{Test 1: assessment of OMIP auction equilibrium prices}

\subsection{Test 1 methodology}

As mentioned in the Introduction, the Spanish local distribution companies (and the Portuguese last resort supplier) are obliged to purchase during the second half of year $20065 \%$ of their regulated power supplies (10\% from year 2007 onwards) in OMIP call auctions. If they do not comply with such obligations, each national regulation establishes different penalties. Due to that fact, those companies are satisfactorily purchasing their required amounts in all the OMIP call auctions. According to the legislation mentioned in the Introduction ("Orders ITC"), the cost of the energy purchased by the Spanish distribution companies in the OMIP call auctions is recognised through the resulting equilibrium price of each call auction.

Since the start of OMIP (in terms of quarterly periods, from Q4-06), all the auctioned settled contracts have experienced positive Forward Risk Premia until October 2007 (in terms of quarterly periods, until Q4-07), when a trend change is appreciated and negative risk premia become dominant during quarters Q4-07 and Q1-08. The Forward Risk Premium is again positive along Q2-08, as shown in Fig. 2.

Due to the scarce alternation of different signs of the Forward Risk Premium, Test 1 considers two periods ("positive" premia and "negative" premia) in order to assess for each period the cost of the purchased energy by distribution companies. Test 1 is also completed with another test in which monthly contracts are separately considered from quarterly contracts. In both tests, 3 different reference prices are employed. 
- Resulting auction equilibrium price (" $F_{\mathrm{eq}}$ "): this is the price recognised to the distribution companies, as stated above. It is calculated as the weighted average price of all the volumes acquired by the distribution companies in the call auctions celebrated for each futures contract.

- Average futures price for all the quotation period (" $F_{\text {all"): }}$ this is the average price of all the daily settlement prices published by OMIP along the whole quotation period of the futures contract. The algorithm employed by OMIP for determining the daily settlement price, based on the traded prices and the bid-ask spread, is described in Section C.6 (settlement price calculation) of OMIP OMIClear Operational Guide (version of June 2008). OMIP is the market operator and OMIClear is the clearinghouse. The algorithm can be summarised as follows:

- The settlement price for a futures contract is the last traded price if it is within the closing bid-ask spread.

- If the last traded price during the trading session is not situated in the closing bid-ask spread, the settlement price is the bid or ask price closest to the last traded price.

- If there is no traded price during the trading session, the settlement price is the average of the bid-ask corresponding to the closing spread.

- If there is no traded price during the trading session, and no closing bid-ask spread, the settlement price corresponds to the settlement price of the previous trading session

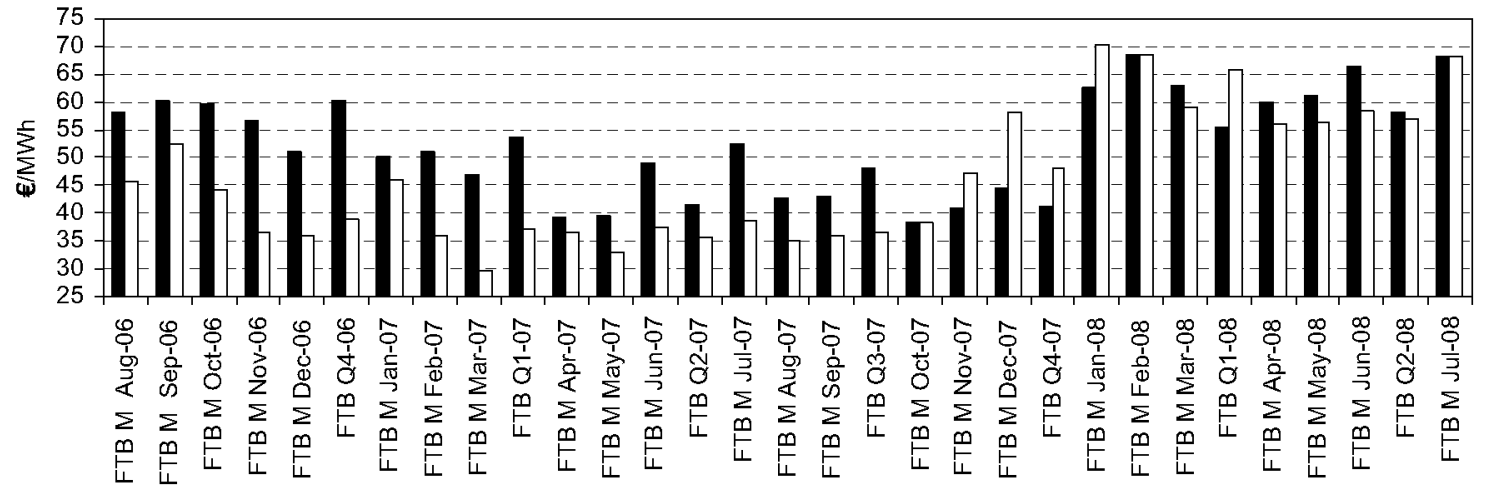

口 OMIP Call Auction Weighted Average Price (€/MWh) $\square$ Underlying Spot Price (€/MWh)

Fig. 2. Evolution of resulting weighted average equilibrium price in OMIP call auctions versus average underlying spot price $(€ / M W h)$
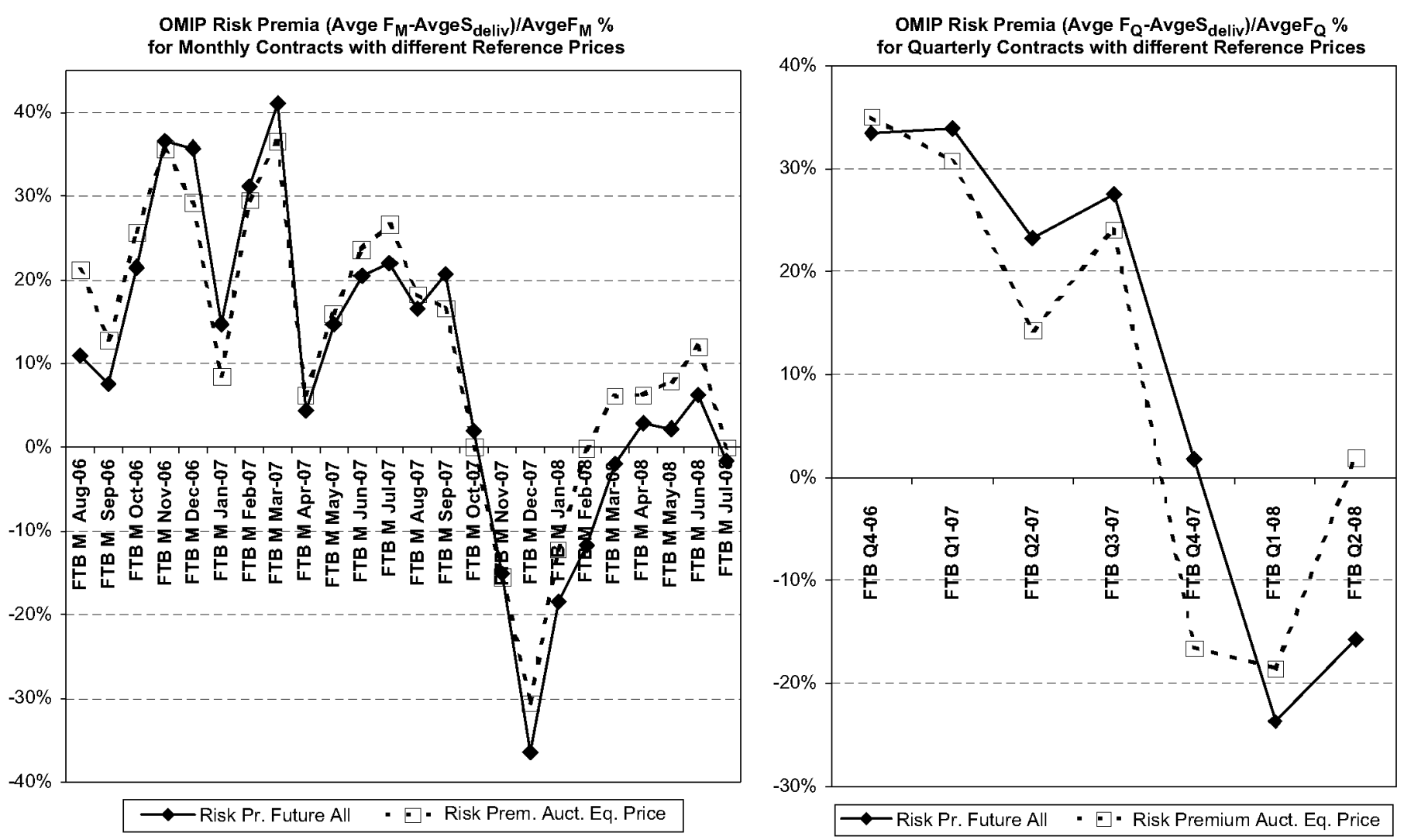

Fig. 3. OMIP risk premia in different quotation periods with different reference prices. 
- Nonetheless, when OMIP does not rely on the resulting price due to scarce negotiation of the contract, OMIP consults a Price Committee and the daily price is obtained from representative quotations of the OTC market. Additionally, OMIP often employs the arbitrage criterion between a quarterly contract and their comprised monthly ones, to obtain the settlement prices by using weighted averages among these 4 contracts. It also applies arbitrage criterion between a calendar contract and their comprised quarterly ones. This is due to the fact that as other forward market mechanisms coexist with OMIP call auctions (OTC, EPE auctions, and CESUR auctions, as previously described in Section 2 Iberian power futures market), the most traded contracts in OMIP are the prompt months and quarterly ones (quarterly contracts with the same maturity as those from EPE and CESUR auctions), being the settlement prices of the least traded contracts in OMIP obtained through this arbitrage criterion.

- Average Spot price ("S"): this is the average price resulting from the Spanish Power Pool day-ahead prices and corresponding to the whole delivery period of the considered futures contract. This Power Pool is managed by OMIE (market operator of the Iberian Energy Market, Spanish Pool, known traditionally as "OMEL")

\subsection{Test 1 results}

Fig. 3 shows the evolution of $\Delta_{\text {ex-post\% }}$ according to the three reference prices stated in the methodology and the two quotation periods considered.

Table 1 shows the economic results for each of the two observed periods for the Forward Risk Premium and the total values according to the three reference prices.

From Fig. 3 and Table 1 it can be observed that $F_{\text {all }}$ provides smaller economic values both for the positive and negative premia periods than the official recognised price $\left(F_{\mathrm{eq}}\right)$. Therefore, the total economic costs do differ depending on which futures price is considered as reference. For the considered data set, the total economic cost of the difference between the reference future price and the spot price $F_{\text {eq-spot }}(74,318,226 €)$ is $31 \%$ bigger than $F_{\text {all }}{ }^{-}$ spot $(56 ., 32,202 €)$. Additionally, from Fig. 3 it is shown that Forward Risk Premium with $F_{\text {all }}$ is less than Forward Risk Premium with $F_{\text {eq }}$ along year 2008

Another analysis is performed for the total economic costs by distinguishing per contract type (monthly versus quarterly), as shown in Table 2. From Table 2, it is shown that the costs of monthly contracts are $2,9 \%$ higher considering the official recognised price $\left(F_{\mathrm{eq}}\right)$ instead of the average quotation price $\left(F_{\text {all }}\right)$. Nonetheless, for the quarterly contracts, the costs with $F_{\text {eq }}$ are less $(-0.7 \%)$. Such a difference in the costs show that there may be more competitive pressure in OMIP call auctions for the quarterly contracts than for the monthly ones. This can be provoked by the interaction with the other coexisting MIBEL market mechanisms (EPE and CESUR auctions) where quarterly contracts are also traded. However, this claim is not as strong as $F_{\text {eq }}$ has resulted bigger than $F_{\text {all }}$ for the already expired quarterly contracts of year 2008 (Q1-08 and Q2-08). The results for the next two quarters (Q3-08 and Q4-08) will reinforce or reject this hypothesis about the competitive nature of OMIP quarterly call auctions.

On the other hand, $t$-Student tests, separately done for monthly and quarterly futures, considering two tails and heteroskedasticity, show no evidence (test result provides a probability value of $62.6 \%$ for monthly futures and $84.3 \%$ for quarterly futures) for assuming same average values for $F_{\text {all }}$ and $F_{\text {eq. }}$.

Fig. 4 shows the evolution of $F_{\mathrm{eq}}$ and $F_{\text {all }}$ for the quarterly contracts. Additionally, it shows the evolution of weighted averages of the underlying monthly average spot prices ("OMIE", also known as "OMEL") for each quarterly delivery period. The conclusions obtained from Fig. 3, Tables 1 and 2 are also found in this figure. Furthermore, comparison with the weighted averages of the monthly contracts is provided ( $F_{\text {eq }}^{*}$ and $F^{*}$ all). It can be appreciated that $F_{\text {eq }}^{*}$ and $F_{\text {all }}^{*}$ are smaller than $F_{\text {eq }}$ and $F_{\text {all }}$, respectively, until the end of year 2007, but during year 2008 the situation is reversed. The spread between $F_{\mathrm{eq}}$ and $F_{\text {eq }}^{*}$ is smaller than between $F_{\text {all }}$ and $F_{\text {all. }}^{*}$. Additionally, the spread between $F_{\text {eq }}^{*}$ and $F_{\text {all }}^{*}$ is smaller than between $F_{\text {eq }}$ and $F_{\text {all }}$.

From the results obtained, the following conclusions can be drawn:

- In the short term, until enough liquidity is reached in OMIP continuous market, it seems reasonable to continue arranging compulsory call auctions for the Spanish Distribution Companies. Nonetheless, the equilibrium price $\left(F_{\mathrm{eq}}\right)$, used for the settlement of the purchased contracts, is resulting slightly higher compared to the average of settlement prices along the trading period of the contract $\left(F_{\text {all }}\right)$. According to OMIP trading limits for mitigating the members' credit risk - as theoretically defined in Section B2.12 Daily Price Variation Limits of OMIP Operational Guide and practically specified in (OMIP, Notice 04/2006) regarding maximum price variation limits - accepted bids and offers must be contained within an interval centered on the trading session reference price, i.e., the resulting settlement price of the previous session. In case of yearly and quarterly contracts, the interval spans from the reference price $\pm 6 \%$ ( $\pm 9 \%$ for monthly contracts; $\pm 15 \%$ for weekly contracts). Spanish distribution companies and Portuguese last resort supplier submit their compulsory bids in OMIP call auctions at the price given by the upper limit of the interval, in order to ensure that their bids are matched. If they submitted their bids at a maximum price which is somehow less, the resulting equilibrium price might diminish, as desired in terms of economic costs to the regulated supplies. Therefore, it makes sense that as soon as the settlement price of the previous

Table 1

Costs assessment of energy purchased in OMIP call auctions by Spanish distribution companies.

Costs assessment of energy purchased in OMIP auctions by Spanish distribution companies

\begin{tabular}{|c|c|c|c|c|}
\hline Period & MWh & $€ F_{\text {all }}$ & $€ F_{\mathrm{eq}}$ & $€$ Spot \\
\hline Positive forward risk premium: July 2006-September 2007 and April 2008-July 2008 (Q4-06-Q3-07 and Q2-Q8) & $14,097,571$ & $734,626,089$ & $748,536,130$ & $629,181,275$ \\
\hline Negative forward risk premium: October 2007-March 2008 (Q4-07-Q1-08) & $7,677,216$ & $387,684,679$ & $391,360,662$ & $436,397,291$ \\
\hline Total & $21,774,787$ & $1,122,310,768$ & $1,139,896,792$ & $1,065,578,566$ \\
\hline
\end{tabular}

Distinction per forward risk premium nature.

Source: OMIP and OMIE. 
Table 2

Costs assessment of energy purchased in OMIP call auctions by Spanish distribution companies.

\begin{tabular}{lccc}
\hline Costs assessment of energy purchased in OMIP auctions by Spanish distribution companies & & \\
\hline Contract type & MWh & $€ F_{\text {all }}$ & $\in F_{\mathrm{eq}}$ \\
\hline Monthly & $13,896,691$ & $722,027,227$ & $742,311,612$ \\
Quarterly & $7,878,096$ & $400,283,541$ & $397,585,180$ \\
& & & $680,792,606$ \\
Total & $21,774,787$ & $\mathbf{1 , 1 2 2 , 3 1 0 , 7 6 8}$ & $1,139,896,792$ \\
\hline
\end{tabular}

Distinction per contract type.

Source: OMIP and OMIF

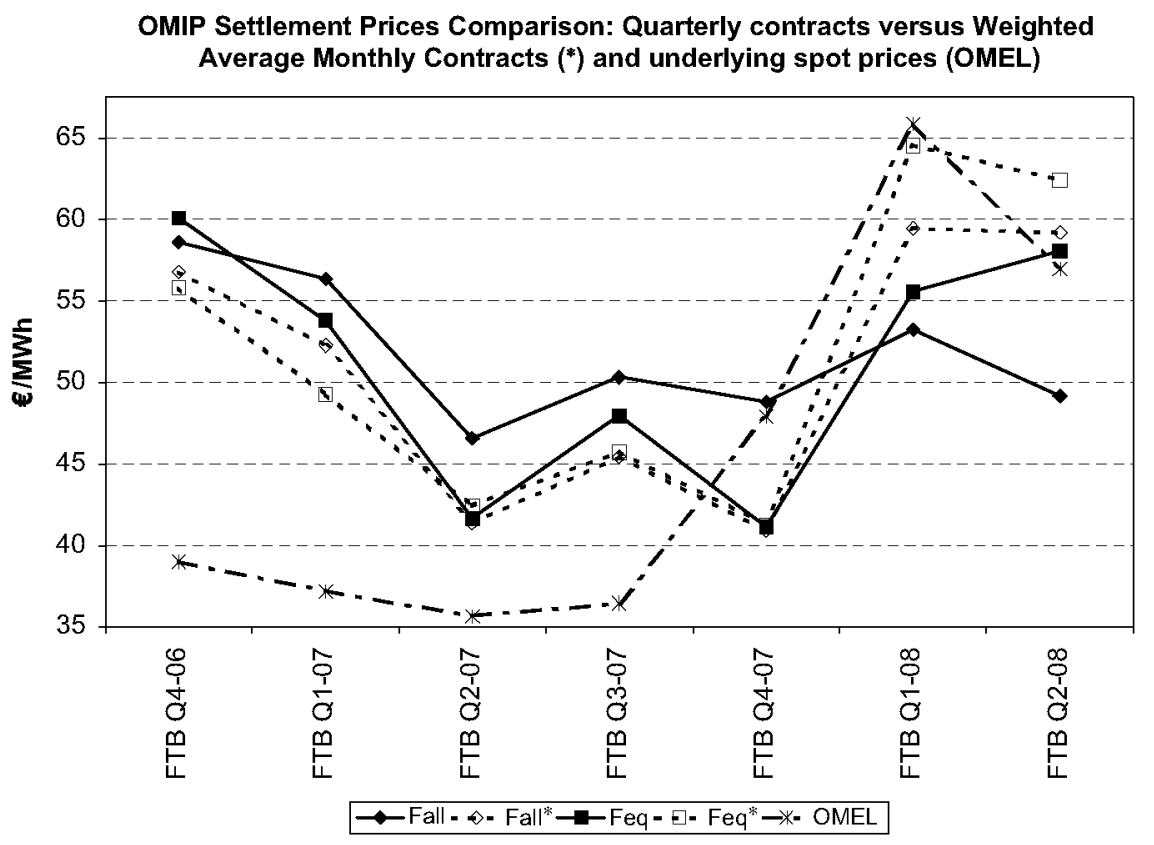

Fig. 4. Comparison of OMIP settlement prices: quarterly contracts versus weighted average monthly contracts $\left({ }^{*}\right)$ and underlying spot prices (OMEL).

session is determined, OMIP and MIBEL Regulators Committee may agree upon a cap price for the compulsory call auction of the following day. Such a cap price would be carefully calculated per auction, in order to get the desired effect on the auction equilibrium price without preventing competition on the sales curve. The cap price would only apply for the compulsory call auction, not for the continuous market. For the sake of transparency, the auction cap price should be published in OMIP bulletin together with the results of the trading session previous to the compulsory call auction. This daily bulletin shows, per negotiated futures contract, all the traded volumes in OMIP continuous market, compulsory call auctions, and OTC settled by OMIClear. Furthermore, last traded price, open price, daily high and low prices, closing bid-ask spread, aggregated traded volumes distinguishing between financial and physical settled contracts (excluding OTC settled by OMIClear), and open interest are also shown.

- It may be reasonable to continue offering compulsory quantities via OMIP call auctions to distribution companies (substituted by last resort suppliers in the coming future) until desired liquidity levels are reached in the continuous market At that stage, the settlement price published by OMIP should accurately reflect market prices and could be better utilised for the calculation of last resort supply costs. The last resort suppliers would then be able to cover their forward energy needs through OMIP continuous market. Therefore, further compulsory OMIP call auctions would no longer be necessary. Additionally, the competitive nature of the continuous market would theoretically provide fewer prices than compulsory auctions, making the supply costs more affordable to last resort suppliers.

\section{Test 2: analysis of basic statistics of futures and spot prices}

\subsection{Test 2 methodology}

Basic statistics (average, median, maximum, minimum, standard deviation, asymmetry coefficient, and kurtosis) for the monthly and quarterly futures contracts and their underlying average spot prices are provided in order to compare all the energy markets considered. The data set is comprised of the arithmetical mean values for the settlement prices of each futures contract during its quotation period. For the corresponding spot price, arithmetical mean for the underlying delivery period is calculated. 


\subsection{Test 2 results}

Tables 3 and 4 show basic statistics for the monthly and quarterly futures prices, respectively: From the information reflected in the tables, the following conclusions can be drawn:

- Within each market and comparing futures with spot values, the same behaviour is detected for monthly and quarterly contracts, except for asymmetry and kurtosis. Nevertheless, as the data set is quite limited (especially for quarterly contracts), such differences are not relevant.

- The average risk premia are positive in power and gas markets, but negative in oil and coal markets. To be more precise, in power and gas markets the average risk premia of positive values tend to be bigger in absolute value than average risk premia of negative values. In oil and coal markets, the average risk premia of negative values tend to be bigger in absolute value than average risk premia of positive values.

- According to standard deviation values, spot markets show bigger volatility than their related futures markets, except for gas market. Due to that bigger volatility, more extreme values are presented in spot markets, with the exceptions of maximum values in gas forward market and minimum values in oil and coal futures markets. The biggest spreads (futures versus spot) regarding maximum values are produced for the oil and coal markets.
- In general, asymmetry tends to be positive and kurtosis tends to be negative.

- Although not reflected in the tables, similar results (except for asymmetry of quarterly contracts) are obtained from OMIP $F_{\text {eq }}$ as those shown for OMIP $F_{\text {all }}$.

\section{Test 3: analysis of $A_{\text {ex-post\% magnitudes }}$}

\subsection{Test 3.1: assessment of forward risk premium existence}

\subsubsection{Test 3.1 methodology}

For all the markets considered, distinguishing between monthly and quarterly futures contracts $\left(F_{\text {all }}\right)$, a $t$-Student test is performed to detect, for each market, if the positive $\Delta_{\text {ex-post\% }}$ and the negative $\Delta_{\text {ex-post\% }}$ have the same average value (i.e., if the risk premium tends to 0 , there would not be evidence of its existence). The $t$-Student test is done considering two tails and heteroskedasticity.

\subsubsection{Test 3.1 results}

$t$-Student tests performed for each market (except for EEX ARA Coal where all the Forward Risk Premia are negative for every month in both monthly and quarterly contracts), and distinguishing between monthly and quarterly contracts, render extremely low probability values rejecting the null hypothesis of no

Table 3

Basic statistics of $F_{\text {all }}$ and underlying spot prices of monthly futures contracts during period August 2006-July 2008 .

\begin{tabular}{|c|c|c|c|c|c|c|c|c|c|c|c|c|}
\hline & \multicolumn{12}{|c|}{ Basic statistics of average reference prices of monthly contracts and underlying spot prices. period: August 2006-July 2008 } \\
\hline & \multicolumn{2}{|c|}{ OMIP (€/MWh) } & \multicolumn{2}{|c|}{ Powernext (€/MWh) } & \multicolumn{2}{|c|}{ Nord Pool (€/MWh) } & \multicolumn{2}{|c|}{ NBP (GB p/them) } & \multicolumn{2}{|c|}{ Brent (US \$/Bbl) } & \multicolumn{2}{|c|}{ EEX ARA (US $\$ / t$ ) } \\
\hline & Futures & Spot & Futures & Spot & Futures & Spot & Futures & Spot & Futures & Spot & Futures & Spot \\
\hline Average & 51.74 & 46.82 & 54.61 & 47.97 & 43.45 & 35.94 & 47.76 & 37.99 & 64.81 & 82.20 & 87.02 & 103.87 \\
\hline Median & 53.02 & 45.06 & 54.77 & 42.55 & 44.81 & 34.91 & 43.75 & 33.86 & 63.25 & 74.99 & 71.86 & 82.34 \\
\hline Max & 67.16 & 70.22 & 82.89 & 88.33 & 63.17 & 66.48 & 80.08 & 62.18 & 77.64 & 133.18 & 154.32 & 209.73 \\
\hline Min & 38.35 & 29.68 & 27.87 & 27.02 & 23.77 & 16.53 & 26.48 & 16.24 & 51.02 & 53.91 & 62.63 & 65.70 \\
\hline Std. Dev. & 8.29 & 12.36 & 15.95 & 18.61 & 12.42 & 13.73 & 15.69 & 15.35 & 6.16 & 23.76 & 26.66 & 41.59 \\
\hline Asymmetry & -0.21 & 0.56 & 0.03 & 0.50 & -0.01 & 0.63 & 0.71 & 0.27 & 0.12 & 0.92 & 1.15 & 1.01 \\
\hline Kurtosis & -1.01 & -0.96 & -0.93 & -1.08 & -1.15 & -0.23 & -0.11 & -1.45 & 0.31 & -0.08 & 0.21 & 0.19 \\
\hline
\end{tabular}

Source: OMIP, OMIE, Powernext, Nord Pool, EEX, Platts, Argus McCloskey.

Table 4

Basic statistics of $F_{\text {all }}$ and underlying spot prices of quarterly futures contracts during period Q4.2006-Q2-2008.

\begin{tabular}{|c|c|c|c|c|c|c|c|c|c|c|}
\hline & \multicolumn{10}{|c|}{ Basic statistics average reference prices quarterly contracts and underlying spot prices. period: Q4-06-Q2-08 } \\
\hline & \multicolumn{2}{|c|}{ OMIP (€/MWh) } & \multicolumn{2}{|c|}{ Powernext $(€ / \mathrm{MWh})$} & \multicolumn{2}{|c|}{ Nord Pool ( $€ / M W h)$} & \multicolumn{2}{|c|}{ NBP (GB p/therm) } & \multicolumn{2}{|c|}{ EEX ARA (US $\$ / t)$} \\
\hline & Futures & Spot & Futures & Spot & Futures & Spot & Futures & Spot & Futures & Spot \\
\hline Average & 51.86 & 45.58 & 54.69 & 47.87 & 40.26 & 32.73 & 49.41 & 37.64 & 73.01 & 102.32 \\
\hline Median & 50.31 & 39 & 51.09 & 41.72 & 38.80 & 34.61 & 41.46 & 30.53 & 69.51 & 86.02 \\
\hline $\operatorname{Max}$ & 58.57 & 65.86 & 70.06 & 72.71 & 48.72 & 44.60 & 76.11 & 60.58 & 86.85 & 158.63 \\
\hline Min & 46.57 & 35.70 & 41.08 & 29.35 & 33.34 & 19.74 & 30.36 & 20.20 & 66.14 & 67.39 \\
\hline Std.Dev. & 4.36 & 11.83 & 11.56 & 19.05 & 5.48 & 9.91 & 16.86 & 15.79 & 7.65 & 37.01 \\
\hline Asymmetry & 0.55 & 1.02 & 0.25 & 0.30 & 0.51 & -0.14 & 0.86 & 0.40 & 1.21 & 0.59 \\
\hline Kurtosis & -1.05 & -0.42 & -1.97 & -2.38 & -0.78 & -1.87 & -0.72 & -1.70 & 0.40 & -1.63 \\
\hline
\end{tabular}

Source: OMIP, OMIE, Powernext, Nord Pool, EEX, Platts, Argus McCloskey. 
existence (or "zero-value") for the Forward Risk Premium. Therefore, the results of the test justify the existence of positive and negative Forward Risk Premia. Table 5 shows the insignificant probability values.

\subsection{Test 3.2: comparison of futures behaviour towards maturity}

\subsubsection{Test 3.2 methodology}

For all the markets considered, distinguishing between monthly and quarterly futures contracts, and per approach to maturity (all quotation period (" $F_{\text {all }}$ "), $3 r$ last month of quotation (" $F_{\mathrm{M}-3}$ "), 2nd last month of quotation (" $F_{\mathrm{M}-2}$ "), and last month of quotation ("F $F_{\mathrm{M}-1}$ ")), different magnitudes are compared:

- Assessment of similar behaviour between monthly and quarterly contracts.

- Quantitative comparison of $A_{\text {ex-post\% }}$ between monthly and quarterly contracts.

- Quantitative comparison of $\Delta_{\text {ex-post\% }}$ between periods with positive or negative values.

Table 5

t-Student test regarding null hypothesis of no existence ("zero-value") for the forward risk premium.

\begin{tabular}{llllll}
\hline & \multicolumn{4}{l}{ t-Student test, null hypothesis: "zero" forward risk premium } \\
\cline { 2 - 6 } & OMIP & Powernext & Nord Pool & NBP & Brent \\
\hline PMonthly & 0.00068026 & 0.00082985 & 0.00000032 & 0.00000002 & 0.00000014 \\
PQuarterly & 0.00216445 & 0.00068821 & 0.00078747 & 0.00248197 & n.a. \\
\hline
\end{tabular}

Source: OMIP, OMIE, Powernext, Nord Pool, Platts.
- Correlation between futures series $\left(F_{\text {all }}\right.$ versus $F_{\mathrm{M}-3}, F_{\mathrm{M}-2}$, or $\left.F_{\mathrm{M}-1}\right)$.

- Samuelson's hypothesis (1965): "Volatility increases as Futures contracts approach maturity".

- Increasing convergence to spot price (less $\Delta_{\text {ex-post\% }}$ in absolute value) with maturity.

\subsubsection{Test 3.2 results}

Fig. 5 shows the evolution of the Forward Risk Premia (in percentage) for both monthly and quarterly OMIP futures contracts, considering the 4 series of futures prices: $F_{\text {all }}, F_{\mathrm{M}-3}$, $F_{\mathrm{M}-2}$, and $F_{\mathrm{M}-1}$. Figs. 6-10, respectively, show the equivalent information for the rest of considered energy markets in this research, namely: Powernext, Nord Pool, NBP Gas, Brent, and EEX ARA Coal.

By analysing all these charts, various trends are detected. The following conclusions can be drawn from Figs. 5-10:

- Monthly and quarterly contracts have similar Forward Risk Premium variation trends coinciding with alternant periods of positive $\Delta_{\text {ex-post\% }}$ or negative $\Delta_{\text {ex-post } \% \text {. In case of power }}$ markets, a general trend change ("positive to negative") is produced in autumn 2007.

- Quantitative variations of $\Delta_{\text {ex-post\% }}$ are similar for monthly and quarterly contracts. Whereas monthly average values tend to be slightly smaller than quarterly ones, extreme monthly values tend to be somewhat bigger than quarterly ones, explained by slightly bigger volatility of the monthly values (measured in terms of standard deviation). Regarding extreme variations, the smallest ones occur for OMIP (around $\pm 40 \%$ ), and the biggest for NBP (around $\pm 80 \%$ ).
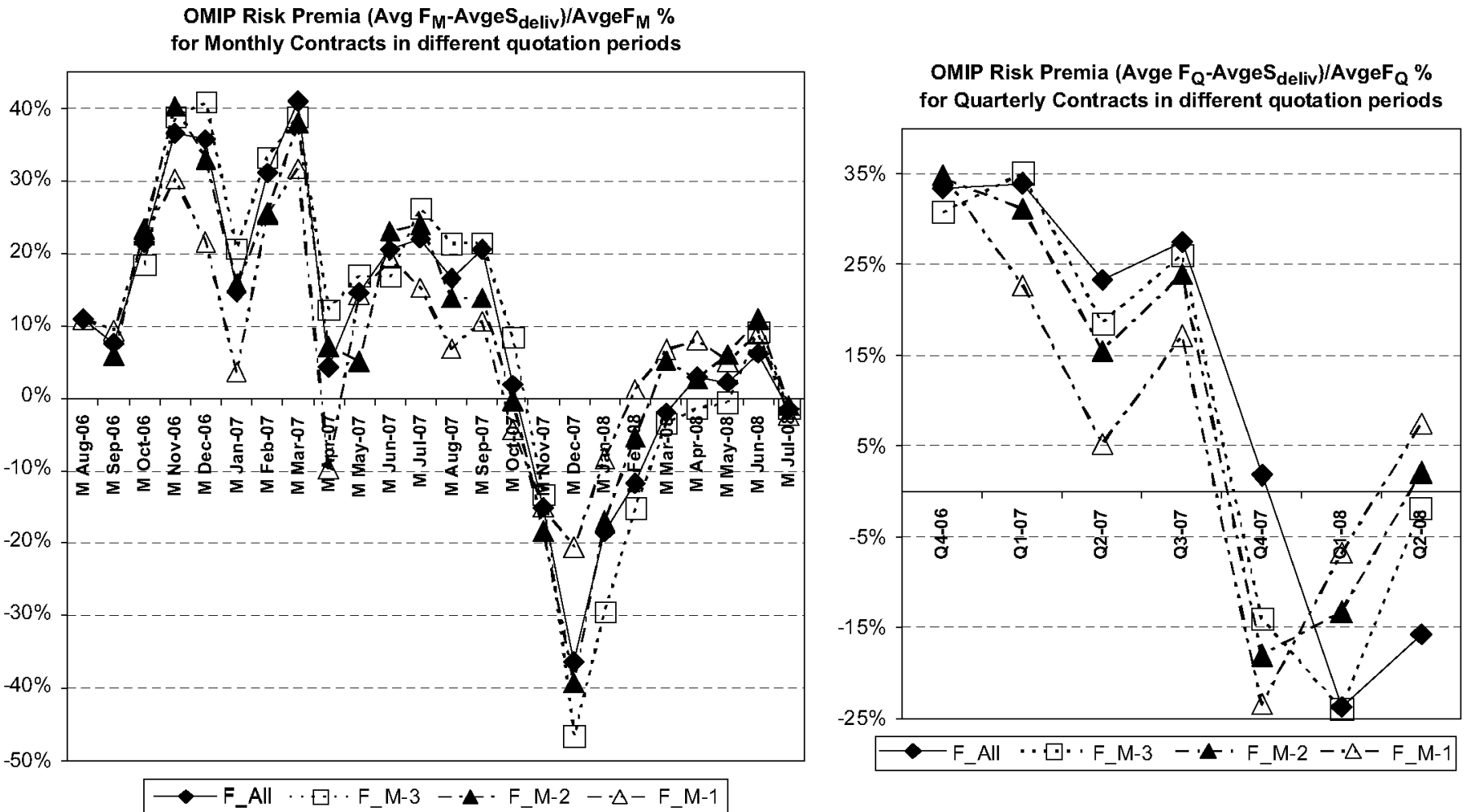

Fig. 5. OMIP Forward Risk Premia distinguishing reference prices per approach to maturity. 

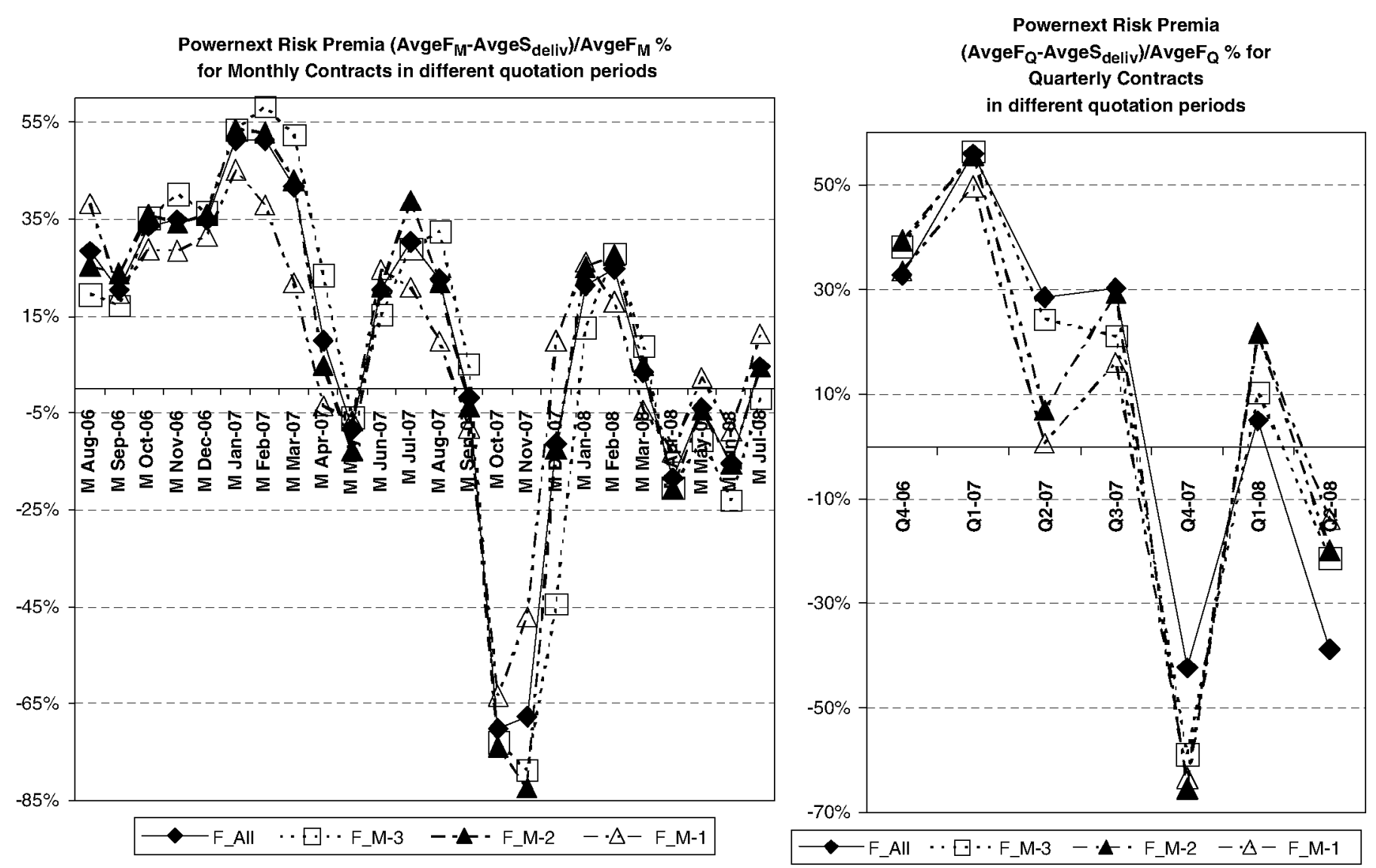

Fig. 6. Powernext Forward Risk Premia distinguishing reference prices per approach to maturity.
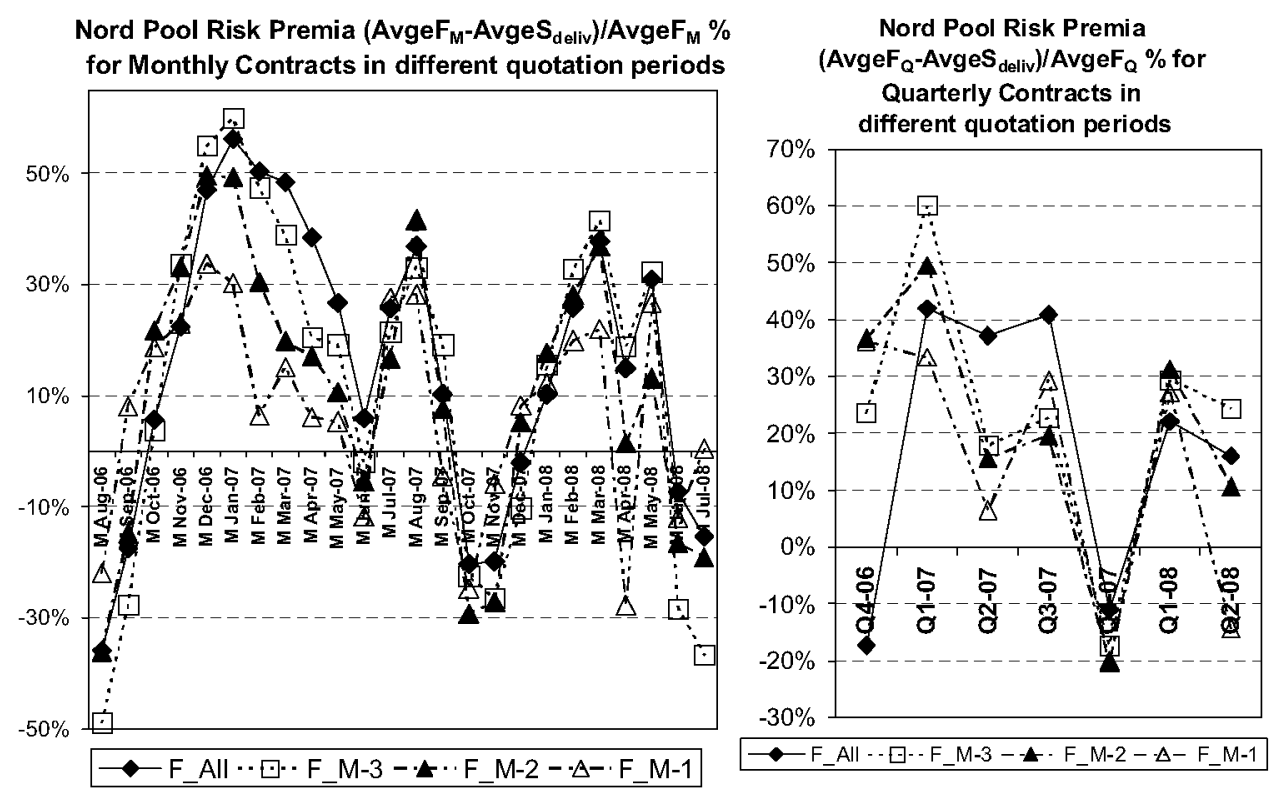

Fig. 7. Nord Pool Forward Risk Premia distinguishing reference prices per approach to maturity.

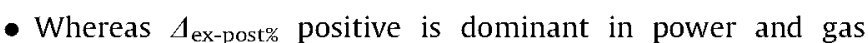
markets, $A_{\text {ex-post\% }}$ negative is dominant in oil and coal markets, supposing different hedging strategies within each market. In absolute value, positive $\Delta_{\text {ex-post } \%}$ tends to be slightly bigger than negative $\Delta_{\text {ex-post } \%}$.
- Correlation between futures series ( $F_{\text {all }}$ with each of the 3 series $F_{\mathrm{M}-3}, F_{\mathrm{M}-2}$, or $\left.F_{\mathrm{M}-1}\right)$ - analysing separately monthly and quarterly futures contracts - is only significant in EEX ARA Coal (correlation coefficient around 0.99). In case of power markets, for the monthly contracts the correlation coefficients are 

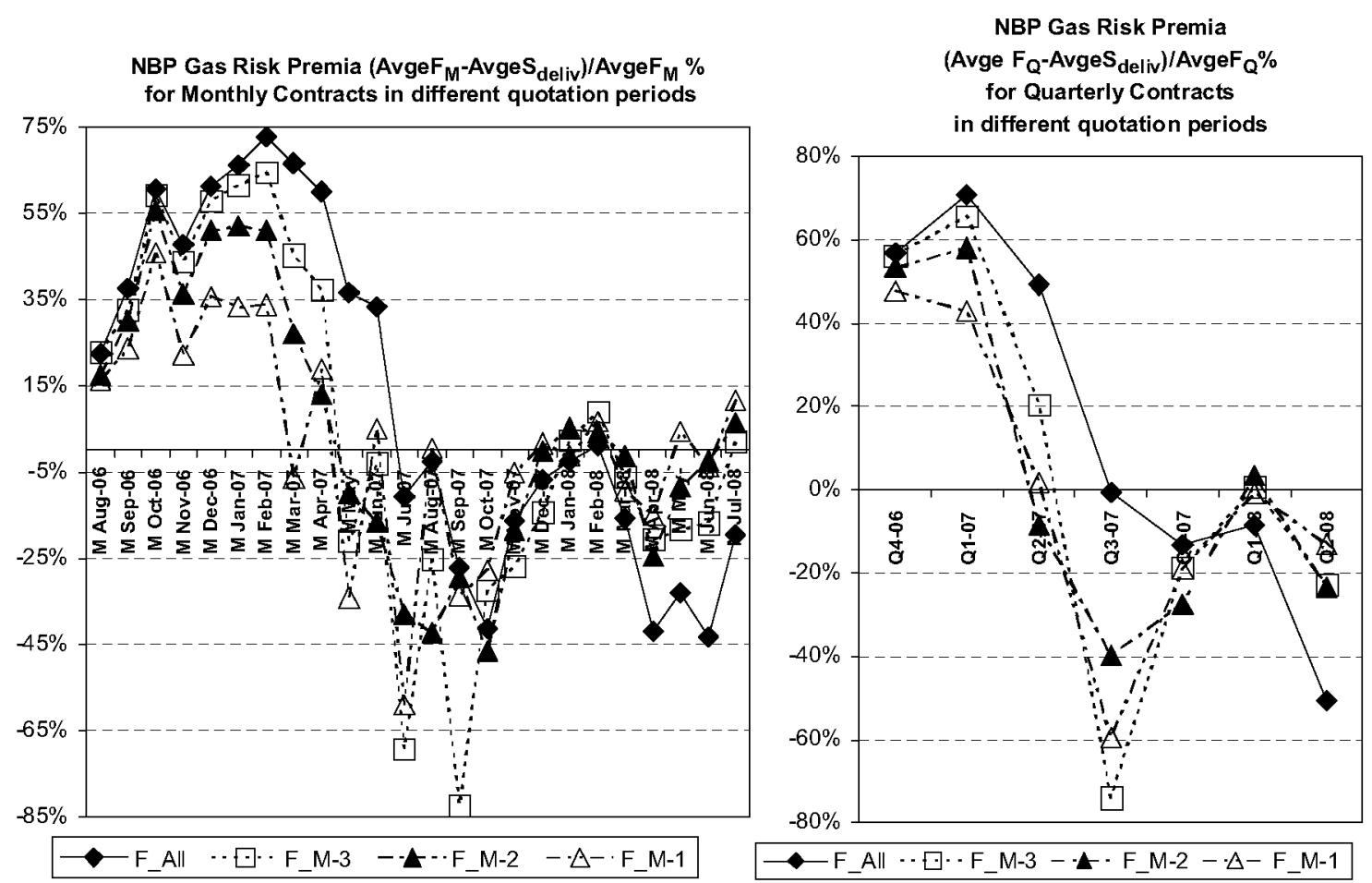

Fig. 8. NBP Gas Forward Risk Premia distinguishing reference prices per approach to maturity.

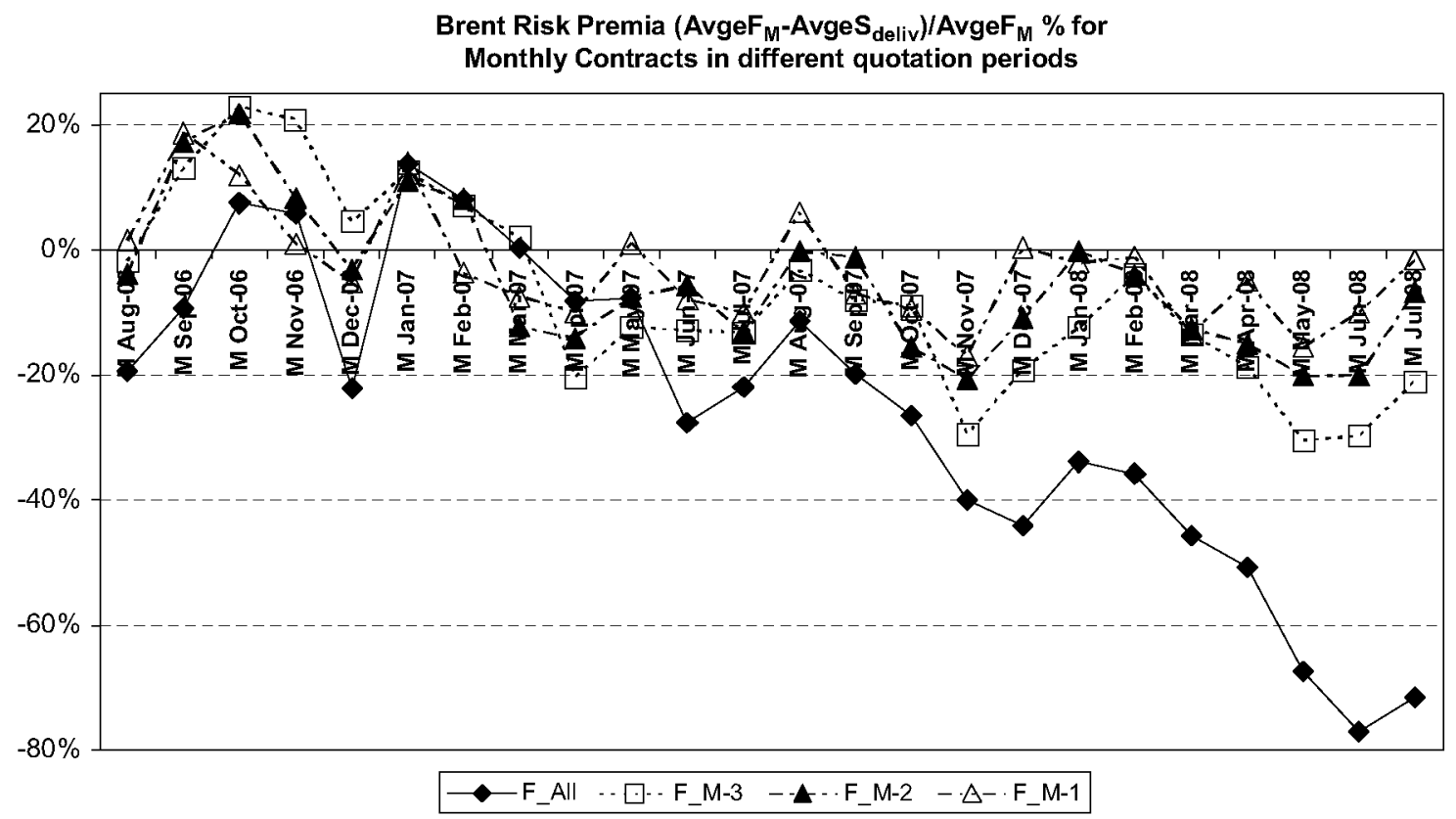

Fig. 9. Brent Forward Risk Premia distinguishing reference prices per approach to maturity.

around 0.90 and for the quarterly contracts, the correlation coefficients are around 0.60 . Smaller coefficients for quarterly contracts can be caused by the limited data set ( 7 values) compared to wider monthly data set (24 values). Comparing power markets, Powernext presents the biggest correlation coefficients and Nord Pool the smallest ones. For NBP Gas, correlation coefficients are around 0.70 for monthly and quarterly contracts. For Brent, correlation coefficients are around 0.85 (monthly contracts). For all the markets, the least correlation is produced between $F_{\text {all }}$ and $F_{\mathrm{M}-1}$ (i.e., correlation tends to diminish as futures contracts approach maturity).
- Samuelson's maturity effect (increasing volatility when maturity approaches) is only noticeable in OMIP, Powernext, EEX ARA Coal, and Brent.

- Increasing convergence to spot price with maturity is fulfilled by all time series (trend towards smallest $A_{\text {ex-post } \%}$ in absolute value, when comparing, in this sequence, $F_{\mathrm{M}-3}, F_{\mathrm{M}-2}$, and $F_{\mathrm{M}-1}$ ). Monthly and quarterly contracts are analysed separately, where comparison of $\boldsymbol{A}_{\text {ex-post\% }}$ in absolute value is separately done for positive $\Delta_{\text {ex-post\% }}$ and negative $\Delta_{\text {ex-post\% }}$. The convergence with maturity can be caused due to lack of accuracy in oldest quoted futures prices. 
EEX ARA Coal Risk Premia $\left(\right.$ AvgeF $_{M^{-}}$Avges $\left._{\text {deliv }}\right) /$ AvgeF $_{M} \%$ for Monthly Contracts in different quotation periods

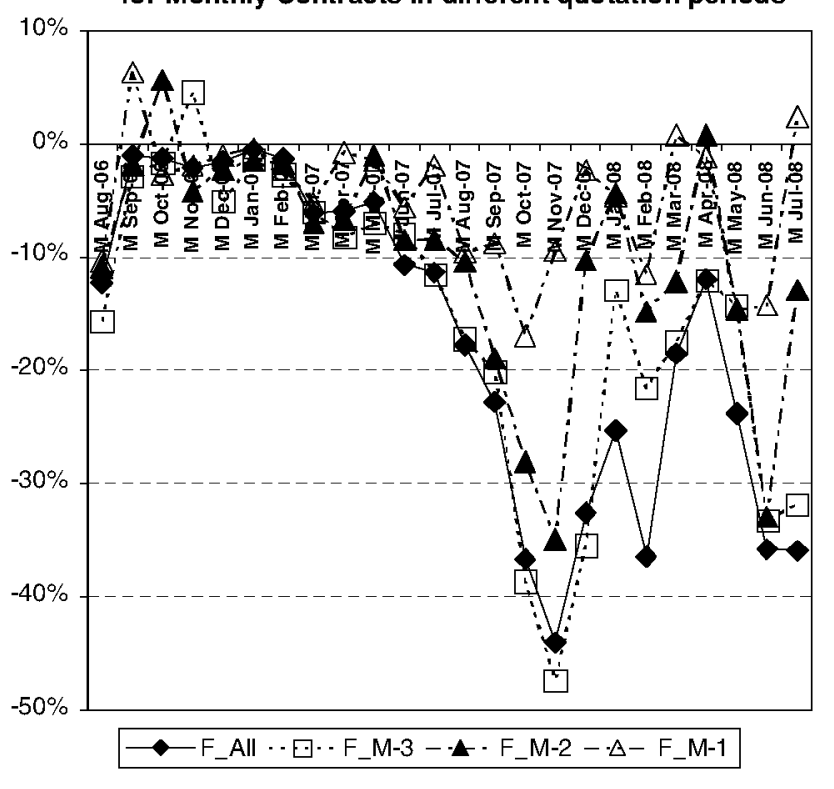

EEX ARA Coal Risk Premia

(Avge $\mathrm{F}_{\mathrm{Q}}-$ AvgeS $\left._{\text {deliv }}\right) /$ AvgeF $_{\mathrm{Q}} \%$

for Quarterly Contracts

in different quotation periods

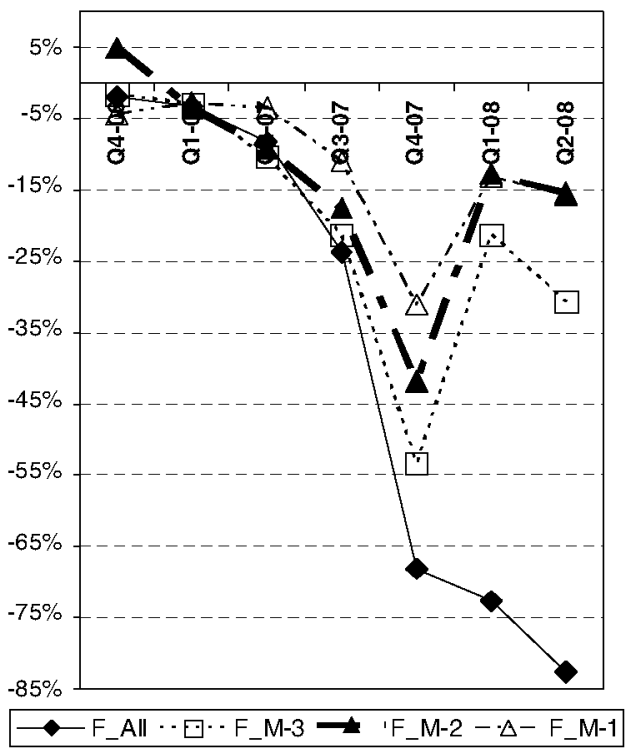

Fig. 10. EEX ARA Coal Forward Risk Premia distinguishing reference prices per approach to maturity.

\section{Test 4: Bessembinder's and Lemmon's hypothesis compliance}

\subsection{Test 4 methodology}

For each futures contract type (monthly and quarterly, distinguishing between $\left.F_{\mathrm{all}}, F_{\mathrm{M}-3}, F_{\mathrm{M}-2}, F_{\mathrm{M}-1}\right)$ of the three considered European Power Markets, testable hypothesis from Bessembinder and Lemmon (2002) is checked by using $A_{\text {ex-post }}$ as the power prices in the 3 markets are commonly expressed in $€ / M W h$ :

$\Delta_{\text {ex-post }}=F_{\mathrm{t}, \mathrm{T}}-$ Average $\left(S_{\mathrm{T}}\right)$

The testable hypothesis is as follows:

"The Forward Risk Premium decreases in the variance of spot prices and increases in the skewness of wholesale prices". In order to test the hypothesis, linear regression is applied according to:

$\Delta_{\text {ex }- \text { post }}=\alpha+\beta * \operatorname{VAR}\left(S_{\mathrm{T}}\right)+\gamma * \operatorname{ASIM}\left(S_{\mathrm{T}}\right)+\varepsilon_{\mathrm{T}}$

where $\alpha$ is a constant, $\beta$ and $\gamma$ are coefficients, $\operatorname{VAR}\left(S_{\mathrm{T}}\right)$ reflects the variance of spot prices, $\operatorname{ASIM}\left(S_{\mathrm{T}}\right)$ represents the non-standardised asymmetry coefficient ("skewness") of spot prices (it is the asymmetry coefficient multiplied by cubed standard deviation of spot prices), and $\varepsilon_{\mathrm{T}}$ is an error term.

Good compliance should render negative $\beta$, positive $\gamma$, with significant values for their $t$-statistics, as well as a high value of $R$ squared statistic. For the $t$-Student tests, a level of confidence of $95 \%$ with 2 tails is considered.

\subsection{Test 4 results}

Table 6 summarises the results of applying multifactor linear regression:

The following conclusions can be drawn from the results summarised in Table 6 :

- In general, there is relatively poor compliance for the three power markets. No significant differences are obtained be- tween the four Futures series considered within each market. In the case of OMIP, similar results are also obtained by using $F_{\text {eq }}$ instead of $F_{\text {all }}$. Although the quarterly contracts are composed of a limited data set per serie ( 7 values versus 24 of the monthly contracts), R-squared statistic is larger for the quarterly contracts.

- OMIP is the least compliant market, as for both monthly and quarterly contracts, coefficient signs for $\beta$ and $\gamma$ are not right as expected from the testable hypothesis, R-squared statistic results too low, and $t$-Student tests (significant values for the coefficients) are not satisfactory.

- Powernext is the best compliant market, as coefficient signs are right, R-squared statistic renders reasonable level, and $t$ Student tests are partly satisfactory.

- Nord Pool has a medium compliance, as the coefficient signs tend to be right, and t-Student tests are partly satisfactory. Reasonable values for $R$-squared statistic are only found for the quarterly contracts.

\section{Conclusions}

Market efficiency is analysed for the Iberian Power Futures Markets and other European Power Markets (Powernext and Nord Pool), and fuel markets (Brent, NBP Natural Gas, and EEX ARA Coal) through evaluation of ex-post Forward Risk Premium. The equilibrium price in OMIP compulsory call auctions for distribution companies is not optimal for remuneration purposes as the purchasing costs for regulated supplies tend to be slightly higher than those from OMIP average settlement prices along the whole quotation period. A regulated cap price for each OMIP compulsory call auction could be transitorily applied in order to obtain a lower equilibrium price and therefore diminish regulated costs of supply. Once OMIP continuous market has acceptable liquidity, the settlement price itself would reflect more accurately the market prices and could be used for evaluating the cost of last resort supplies. In the period considered (August 2006-July 2008), monthly futures contracts have a similar behaviour as quarterly 
Table 6

Regression results regarding compliance with Bessembinder's and Lemmon's hypothesis.

\begin{tabular}{|c|c|c|c|c|c|c|c|c|}
\hline Quot. period & $\alpha$ & $\beta$ & $\gamma$ & $\mathrm{R}^{2}(\%)$ & $t$ & $\mathrm{t}_{\alpha}$ & $\mathrm{t}_{\beta}$ & $\mathbf{T}_{\gamma}$ \\
\hline \multicolumn{9}{|c|}{ OMIP M contracts } \\
\hline All & 4.75 & 0.0177 & -0.0034 & 0.07 & 2.08 & 1.34 & 0.10 & -0.12 \\
\hline$M-3$ & 5.38 & -0.0056 & 0.0005 & 0.00 & 2.09 & 1.23 & -0.02 & 0.01 \\
\hline$M-2$ & 5.84 & -0.0386 & 0.0009 & 0.48 & 2.09 & 1.66 & -0.21 & 0.03 \\
\hline M-1 & 3.63 & 0.0358 & -0.0060 & 0.47 & 2.08 & 1.49 & 0.28 & -0.31 \\
\hline \multicolumn{9}{|c|}{ OMIP Q contracts } \\
\hline All & 5.83 & -0.0373 & 0.0105 & 1.95 & 2.78 & 0.48 & -0.08 & 0.17 \\
\hline$M-3$ & 7.28 & -0.0943 & 0.0116 & 1.00 & 2.78 & 0.62 & -0.20 & 0.19 \\
\hline$M-2$ & 6.50 & 0.0316 & -0.0098 & 2.58 & 2.78 & 0.62 & 0.08 & -0.18 \\
\hline M-1 & 4.51 & 0.1223 & -0.0268 & 14.48 & 2.78 & 0.51 & 0.34 & -0.58 \\
\hline \multicolumn{9}{|c|}{ Powernext $\mathrm{M}$ contracts } \\
\hline All & 18.32 & -0.0637 & 0.0003 & 60.13 & 2.08 & 5.28 & -3.67 & 2.54 \\
\hline M-3 & 22.50 & -0.0890 & 0.0004 & 64.79 & 2.08 & 5.83 & -4.61 & 3.47 \\
\hline$M-2$ & 19.53 & -0.0669 & 0.0003 & 59.39 & 2.08 & 5.13 & -3.51 & 2.37 \\
\hline M-1 & 12.60 & -0.0337 & 0.0001 & 44.99 & 2.08 & 3.81 & -2.04 & 1.11 \\
\hline \multicolumn{9}{|c|}{ Powemext $Q$ contracts } \\
\hline All & 29.66 & -0.1547 & 0.0010 & 75.36 & 2.78 & 3.39 & -2.62 & 2.18 \\
\hline$M-3$ & 27.34 & -0.1211 & 0.0007 & 69.98 & 2.78 & 2.74 & -1.80 & 1.35 \\
\hline$M-2$ & 27.74 & -0.1131 & 0.0006 & 69.48 & 2.78 & 2.66 & -1.61 & 1.15 \\
\hline M-1 & 20.48 & -0.0796 & 0.0004 & 68.58 & 2.78 & 2.24 & -1.29 & 0.82 \\
\hline \multicolumn{9}{|c|}{ Nord Pool M contracts } \\
\hline All & 13.24 & -0.2662 & 0.0092 & 15.02 & 2.08 & 3.35 & -1.93 & 0.28 \\
\hline$M-3$ & 12.99 & -0.2712 & 0.0153 & 10.41 & 2.08 & 2.61 & -1.56 & 0.37 \\
\hline$M-2$ & 10.90 & -0.2520 & 0.0022 & 15.68 & 2.08 & 2.96 & -1.96 & 0.07 \\
\hline M-1 & 6.04 & -0.1224 & -0.0091 & 12.65 & 2.08 & 2.69 & -1.56 & -0.49 \\
\hline \multicolumn{9}{|c|}{ Nord Pool Q contracts } \\
\hline All & 16.82 & -0.2115 & -0.0078 & 43.96 & 2.78 & 2.67 & -1.41 & -0.28 \\
\hline$M-3$ & 13.61 & 0.0424 & 0.0283 & 9.51 & 2.78 & 1.14 & 0.15 & 0.54 \\
\hline$M-2$ & 4.78 & 0.2855 & 0.0642 & 45.35 & 2.78 & 0.59 & 1.47 & 1.81 \\
\hline M-1 & -0.18 & 0.3524 & 0.0783 & 82.26 & 2.78 & -.04 & 3.52 & 4.26 \\
\hline
\end{tabular}

Source: OMIP, OMIE, Powernext, and Nord Pool.

contracts and average risk premia have been positive in power markets (especially until Q4-07) and in gas markets but negative in oil and coal markets. In all the examined markets, the Forward Risk Premium for a futures contract tends to diminish as it approaches maturity. Samuelson's maturity effect (increasing volatility with maturity) is only noticeable in OMIP, Powernext, EEX ARA Coal, and Brent. Compliance with Bessembinder's and Lemmon's testable hypothesis regarding Forward Risk Premium variations in power markets (decreasing with variance of spot prices, and increasing with skewness of spot prices) is relatively low. Further research is proposed considering an enlarged data set (especially with quarterly contracts) to better test all the hypotheses and draw additional conclusions. Inclusion of longer contracts (synthetic joint of two quarters, and calendar contracts) may also be of interest, although such series are still reduced if OMIP starting point (July 2006) is considered. In general, it can be concluded that none of the markets analysed presents a noticeable level of market efficiency as remarkable Forward Risk Premia exist in all the markets. Regarding power markets, the behaviour of OMIP futures prices do not differ much in terms of efficiency compared to more mature markets (Powernext and Nord Pool). Although liquidity is still poor in the Iberian Derivatives Market managed by OMIP, its price efficiency has improved along with OMIP market development and should further increase with upcoming integration of European Power Regional Markets as well as with the development of the coexisting forward contracting mechanisms in the Iberian Energy Market, namely, OTC, EPE auctions, and CESUR auctions. Additionally, due to the relevance of natural gas as power-generation fuel within the Iberian energy mix, further development of the Iberian Natural Gas Market (the so-called MIBGAS) will presumably contribute to indirectly improve the desired OMIP price efficiency. Further research is encouraged to analyse the efficiency gains of the Iberian Derivatives Market caused by the dynamic evolution of the Iberian energy markets.

\section{References}

Arciniegas, I., Barrett, C., Marathe, A., 2003. Assessing the efficiency of US electricity markets. Utilities Policy 11, 75-86.

Armstrong, M., Galli, A., 2005. Are day-ahead prices for electricity converging in Continental Europe? An exploratory data approach. CERNA Working Paper.

Avsar, S., Goss, B., 2001. Forecast errors and efficiency in the US electricity futures market. Australian Economic Papers 40, 479-499.

Bessembinder, H., Lemmon, M.L., 2002. Equilibrium pricing and optimal hedging in electricity forward markets. The Journal of Finance LVII (3) $1347-1382$.

Byström, H., 2003. The hedging performance of electricity futures on the Nordic power exchange Nord Pool. Applied Economics 35, 1-11.

Capitán Herráiz, A., Rodríguez Monroy, C., 2009. Evaluation of the Liquidity in the Iberian Power Futures Market. IV Congress of Spanish Association of Energy Economists (AEEE), Seville (Spain), January 2009.

Cartea, A., Villaplana, P., 2008. Spot price modelling and the valuation of electricity forward contracts: the role of demand and capacity. Journal of Banking and Finance 32, 2502-2519.

Engel, C., 1996. The forward discount anomaly and the risk premium: a survey of recent evidence. Journal of Empirical Finance 3 (2), 123-192.

Federico, G., Vives, X., 2008. Competition and regulation in the Spanish gas and electricity Markets. Reports of the Public-Private Sector Research Center, 1 , IESE Business School, University of Navarra, pp. 117-141.

Fernández Domínguez, E., Xiberta Bernat, I., 2007. Restructuring and generation of electrical energy in the Iberian Peninsula. Energy Policy 35, 5117-5129. 
Furió, D., Meneu, V., 2009. Expectations and Forward Risk Premium in the Spanish Deregulated Power Market. IV Congress of Spanish Association of Energy Economists (AEEE), Seville (Spain), January 2009.

Karakatsani, N.V., Bunn, D.W., 2005. Diurnal Reversals of Electricity Forward Premia. London Business School Working Paper.

Longstaff, F.A., Wang, A.W., 2004. Electricity forward prices: a high-frequency empirical analysis. Journal of Finance 59 (4), 1877-1900.

Martín Martínez, M.J., Villaplana, P., 2009. Los Mercados a Plazo en el Sector Eléctrico, In: Tratado de regulación del sector elêctrico, tomo II: aspectos económicos. (Ed.), Thomson-Aranzadi, Navarra, pp. 437-459.

OMIP: Notice 04/2006Maximum Price Variation Limits, version of 30 June 2006 OMIP OMIClear: MIBEL Derivatives Market Operational Guide, version of June 2008.
Samuelson, P., 1965. Proof that properly anticipated prices fluctuate randomly. Industrial Management Review 6 (2) 41-49.

Serletis, A., 1992. Maturity effects in energy futures. Energy Economics 14, 150-157.

Sveriges Energimyndigheten (STEM), 2006. Finansiella elmarknaden. Bilaga 5: Oversikt av den vetenskapliga litteraturen.

Ullrich, C.J., 2007. Constrained Capacity and Equilibrium Forward Premia in Electricity Markets. Virginia Institute of Technology Working Paper.

Walls, W., 1999. Volatility, volume and maturity in electricity futures. Applied Financial Economics 9, 283-287.

Zachmann, G., 2005. Convergence of Electricity Wholesale Prices in Europe? A Kalman Filter Approach, DIW Discussion Paper, 512. 